\title{
SHEEP HEMATO-BIOCHEMICAL PARAMETERS AND CARCASS CHARACTERISTICS AS AFFECTED BY VITESELEN 15® INJECTION AND TRANSPORTATION
}

\author{
A.Y. Kassab and H. A. Hamdon
}

Department of Animal Production, Faculty of Agriculture, New Valley, University of Assiut, 71526, Egypt

\section{SUMMARY}

Twenty four Farafra male sheep $36.47 \pm 1.04 \mathrm{~kg}$ live body weight and aged 14-16 months were used in this study. The objective of the current study was to evaluate the effects of vitamin E and selenium (Viteselen 15®) injection as antioxidants before transportation during hot season on live body weight (BW) loss, some hematobiochemical parameters and carcass characteristics in New Valley Governorate, Egypt. Animals were divided randomly into three symetric groups (eight each group). The first group was served as control group, while the second and the third were injected with $10 \mathrm{mg} / 10 \mathrm{~kg} \mathrm{BW}$ and $15 \mathrm{mg} / 10 \mathrm{~kg} \mathrm{BW}$ of Viteselen 15®, respectively. Animals were transported in an open truck covering a distance of approximately $300 \mathrm{~km}$ for three hours. Before loading and after transportation, rectal temperature and respiration rates as thermal responses were recorded. Blood samples were collected before and after transportation to study the negative effect of transportation stress. Blood serum was analyzed for $T_{3}, T_{4}$, cortical, total protein, albumin, urea, ALT, AST, creatinine and glucose parameters. In addition, carcass and meat quality parameters were evaluated. The results indicated that there are no significant differences among three groups before transportation in hemato-biochemical parameters. Also, the results illustrated that injection of Viteselen 15® alleviated the adverse effect of transportation stress during hot season. Furthermore, improve carcass characteristics and meat quality by reducing the loss of live body weight after transportation. Thus, the injection of $15 \mathrm{mg} / 10 \mathrm{~kg}$ BW Viteselen 15® as antioxidant especially during hot season before transportation of sheep is recommended

\section{Keywords: Transportation, Viteselen 15®, hemato-biochemical parameters, carcass, sheep}

\section{INTRODUCTION}

The census of sheep in Egypt is estimated about 5.8 million heads, which consider about $14 \%$ of livestock production in Egypt. The total number of sheep in the New Valley Governorates estimated about 139.528 thousand heads, which consider about $30.6 \%$ of livestock production in the New Valley Governorate (Ministry of Agriculture, 2015). Most of sheep production in Egypt is in coastal governorates, while most consumers of mutton are in Cairo. Thus, the transportation of sheep is necessary. New Valley Governorate located in Upper Egypt in Western Desert between $25^{\circ} ; 42$ and $30^{\circ} ; 47 \mathrm{E}$ longitude, $22^{\circ}$ $30 \& 29^{\circ} 30 \mathrm{~N}$ latitude and lies $77.8 \mathrm{~m}$ altitude above the sea level. The climate of this area is arid and dry, essentially that of the desert. Rainfall is almost negligible and the ambient temperature and relative humidity ranged from 42 to $46^{\circ} \mathrm{C}$ and 18 to $33 \%$ respectively during summer days (Kassab and Mohammed, 2014).

Transportation is an important activity of the farming industry. Currently in Egypt there is no regulation ruling over transportation of animals. Transport can be considered as additional stressor to animals. Road transportation of livestock is a stressinducing situation that may lead to variations in hemato-biochemical parameters as indicator for physiological status (e.g cardiovascular, immune and endocrine via the activation of hypothalamopituitary- adrenal gland axis (Broom , 2003 and El
Khasmi et al., 2013). Generally, blood examinations are routinely used in diagnosis of the health status and evaluation of adaptability of livestock to stress factors (Steinhardt, 2002). Also, transportation cause metabolic changes that can in turn adversely affect meat quality (Kannan et al., 2003; Bond et al.,2004 and Jin et al., 2006). Some studies have reported the responses of different physiological parameters to the effect of road transportation stress in animals (Steinhardt and Thielscher, 2000; Ingram et al., 2002 and Kassab and Mohammed, 2014).There was substantial research work on the effects of transportation of cattle, pigs and poultry (Rollin, 1995), while little work was carried out to assess the effects of stress in transported sheep and goats especially under hot and subtropical conditions. Generally, supplementations of vitamin $\mathrm{E}$ and selenium as antioxidants at super nutritional levels has resulted in improvements in animal performances and immune function (Rooke et al., 2004 and Chauhan et al., 2014). Thus, antioxidant supplementation may provide beneficial effect against stress induced tissue damage (Sen, 2001). Kadim et al., 2007 and Bernabucci et al. (2010) reported that transport stress led to major problem for the livestock industry as it impairs animal performance specially during summer months and leading to economic losses globally. Few investigations were carried out in Egypt to study the adverse effect of transportation stress on sheep production. 
Therefore, the objective of this study was to investigate the beneficial effect of Viteselen 15® (vitamin $\mathrm{E}$ and selenium) injection as antioxidant to ameliorate the negative effects of transportation in sheep especially under hot conditions.

\section{MATERIALS AND METHODS}

\section{Experimental design:}

This experiment was carried out in the New Valley Governorate during July in summer season. Twenty four Farafra (local breed in the New Valley) male healthy sheep weighting $36.47 \pm 1.04 \mathrm{~kg}$ and aged 14-16 months were used in this study. Animals were divided randomly into three equal groups (eight/group). On transportation day before feeding and drinking, the sheep were numbered and body weight $(\mathrm{BW})$, rectal temperature, $\mathrm{C}^{-}$(RT) and respiration rate $(\mathrm{RR})$ as thermal responses were recorded. Rectal temperature was recorded using a clinical thermometer (Dong E Digital thermometer, Model No: BT-AIICN; LOT NO: $0911 \mathrm{Mad}$ ). Respiration rate ( $\mathrm{RR}$, breaths/min) was recorded by counting the flank movements. The first group was untreated and served as control group. Whereas, the second (T1) and the third groups (T2) were injected intramuscularly by $10 \mathrm{mg} / 10 \mathrm{~kg}$ and $15 \mathrm{mg} / 10 \mathrm{~kg} \mathrm{BW}$, respectively with a combination of vitamin $\mathrm{E}$ and selenium [Viteselen 15®, Adwia Company, Egypt].Each $\mathrm{ml}$ of viteselen contained $150 \mathrm{mg}$ vitamin $\mathrm{E}$ acetate and $1.67 \mathrm{mg}$ sodium selenite (eq. to $0.762 \mathrm{mg} \mathrm{Se}$ ). The recommendation dosage in pamphlet was $0.5 \mathrm{ml} / 10 \mathrm{~kg} \mathrm{BW}$, but the increase of the injection dosage of the experimental study due to the high temperature and low relative humidity $\left(45^{\circ} \mathrm{C}\right.$ and $20 \%$,respectively) in the day of transportation and in generally, during summer season in the New Valley Governorate. Blood samples before and after transportation from each animal in each groups were collected. Before transportation the sheep were divided into three groups. Immediately after transportation, the previous thermal responses (RT and RR) and BW were recorded and blood samples were taken. The obtained blood samples were analyzed for hematological and biochemical parameters. The handling, loading, and transportation of sheep were performed humanely in accordance with the guidelines governing animal transport welfare by road (Farm Animal Welfare Council, 2003). The sheep were stocked at a rate of $0.27 \mathrm{~m}^{2}$ per animal inside the vehicle. All the handling and loading of animals were conducted between 11:0 a.m. to 12:0 afternoons. The floor of the truck was provided with beddings (wood shavings) covered with rubber mats for secured footing. The journey started by 12:00 a.m. and was terminated at 15:00 p.m. The vehicle travelled for $3.00 \mathrm{~h}$. for about 300 $\mathrm{km}(90-100 \mathrm{~km} /$ hour $)$

\section{Blood sampling and analysis:}

About $10 \mathrm{ml}$ of blood via jugular venipuncture was collected from each sheep in each group before and after transportation. Blood samples were divided into two sterile test tubes, one tube with $0.14 \%$ anticoagulant (EDTA K3, Pty Ltd., Adelaide, SA, Australia) for determination of hematological parameters and the other one without anticoagulant for obtaining serum. The collected blood samples were quickly kept in ice pack and sent to the laboratory. Whole blood samples were analyzed for hematological blood parameters, while serum samples were obtained by centrifugation of blood samples for 15 minutes at 3,000 r.p.m, then dispensed into $1.5 \mathrm{ml}$ Eppendorf tubes and stored at $-20{ }^{\circ} \mathrm{C}$ for analysis of blood composition. Hematological blood parameters were determined using sysmex xp-300 ( Japan). Serum samples of all the animals were assayed for cortisol, triiodothyronine $\left(\mathrm{T}_{3}\right)$ and thyroxine $\left(\mathrm{T}_{4}\right)$ concentrations using radioimmunoassay (RIA) technique. Total protein, albumin, glucose, cholesterol, creatinine, urea, creatine kinase activity, aspartate aminotransferase (AST) and alanine aminotransferase (ALT) were determined using appropriate commercial test kits. The concentrations were measured using standard protocols (Photometer 5010 v5+).

\section{Carcass traits:}

Immediately after transportation, three animals from each group (untreated, T1 and T2) were chosen randomly and slaughtered, to study carcass yield and traits. After slaughter, weight of hot carcass, rumen content and empty body weight were recorded for each animal. The carcasses were disjoined into the following whole sale cuts: legs, lion, rack, shoulders, neck, flank, brisket and tail. The first four cuts were considered as prime cuts, while the latter four were considered as secondary cuts. Weight of each cut was recorded. Also, dressing \% was calculated by using the following equation:

$$
\begin{aligned}
& \text { Dressing } \%(\mathrm{~A})=\frac{\text { hot carcass weight }}{\text { slaughter weight }} \times 100 \\
& \text { Prime cuts } \%=\frac{\text { shoulder }+ \text { legs }+ \text { lion }+ \text { rack, } \mathrm{kg}}{\text { carcass weight, } \mathrm{kg}} \times 100
\end{aligned}
$$

After slaughter the $9^{\text {th }}, 10^{\text {th }}$ and $11^{\text {th }}$ ribs cut of right side were separated as eye muscle. Eye muscle area (L.D, longissimus dorsi) was measured in squared centimeters using planimeter Model LI- 3000, LI COR, U.S.A (Henderson et al., 1966). Water holding capacity (WHC) was estimated by the method of Wierbicki and Deatharage (1968) using the following equation:

\section{$\mathrm{WHC}=\mathrm{A}_{2}-\mathrm{A}_{1}$}

Where:

$\mathrm{A}_{1}=$ Inner area of plasticity (area of meat after pressing) $\mathrm{cm}^{2}$

$\mathrm{A}_{2}=$ Outer area (area of meat plus area of free water after pressing) $\mathrm{cm}^{2}$

Both areas were determined using a planimeter. Values of $\mathrm{pH}$ were measured by using $\mathrm{pH}$ meter (portable Digital Waterproof HANA model HI 9025) after slaughter. 
Statistical analysis:

Data were statistically analyzed using the general liner model producer (GLM) of statistical analysis system SAS (2004) with levels of Viteselen 15® (vitamin $\mathrm{E}$ and selenium) as the main effect as following model:

$\mathrm{Y}_{\mathrm{ij}}=\mu+\mathrm{T}_{\mathrm{i}}+\mathrm{E}_{\mathrm{ij}}$

Where:

$\mathrm{Y}_{\mathrm{ij}}=$ The observation,

$\mu=$ The overall mean,

$\mathrm{T}_{\mathrm{i}}=$ The effect of $\mathrm{i}^{\text {th }}$ level, $\mathrm{i}=1,2$ whereas; $\mathrm{i}=1$

$(10 \mathrm{mg} / 10 \mathrm{kgBW})$ and

$\mathrm{i}=2(15 \mathrm{mg} / 10 \mathrm{kgBW})$

$\mathrm{E}_{\mathrm{ij}}=$ Experimental error assumed to be randomly distributed $(0, \sigma 2)$.

Duncan's multiple range test (1955) was used to compare between means of the untreated group and treated groups (T1 and T2).

\section{RESULTS}

\section{Body weight loss and thermal responses}

Body weight loss values as results of Viteselen15 as antioxidant injection were $2.06 \%$ and $2.60 \%$ in $\mathrm{T} 1$ and $\mathrm{T} 2$, respectively, compared to body weight loss value $(4.38 \%)$ in untreated group (Table 1). The present results indicated that injectionViteselen15as antioxidant led to significantly $(\mathrm{P}<0.05)$ alleviated live weight losses in compare to the untreated group. The differences between the two treated groups were not significant. Also, the results indicated that there was no significant effect of antioxidant injections on rectal temperature (RT).After transportation rectal temperature increased as result of antioxidant injection by $0.59 \%$ and $0.89 \%$ in $\mathrm{T} 2$ and $\mathrm{T} 1$, respectively compared to the same group before transportation. While, rectal temperature of untreated group after transportation increased by $1.74 \%$ compared to the value before transportation.As a result of transportation the increasing of respiration rate values as a result of Viteselen 15 injection were $16.34 \%$ and $12.35 \%$ in $\mathrm{T} 1$ and $\mathrm{T} 2$, respectively compared to the same group before transportation. While, the increasing of respiration rate of untreated group after transportation was $30.53 \%$ compared to the value before transportation.

Table 1. Effect of vitamin $E$ and selenium injection on live body weight loss and thermal responses of transported sheep(Mean \pm SEM)

\begin{tabular}{|c|c|c|c|c|c|c|}
\hline \multirow{3}{*}{ Items } & & & \multicolumn{4}{|c|}{ Treatments } \\
\hline & \multicolumn{2}{|c|}{ Untreated } & \multicolumn{2}{|c|}{$\mathrm{T} 1$} & \multicolumn{2}{|c|}{$\mathrm{T} 2$} \\
\hline & Pre-trans. & Post-trans. & Pre-trans. & Post-trans. & Pre-trans. & Post-trans. \\
\hline $\begin{array}{l}\text { No. of } \\
\text { animals }\end{array}$ & 8 & 8 & 8 & 8 & 8 & 8 \\
\hline $\mathrm{LBW}, \mathrm{kg}$ & $37.19 \pm 1.09$ & $35.56 \pm 0.92$ & $36.98 \pm 1.04$ & $36.02 \pm 0.88$ & $36.94 \pm 1.01$ & $36.18 \pm 1.03$ \\
\hline LBWL, kg & \multicolumn{2}{|c|}{$-1.63 \pm 0.22^{\mathrm{a}}$} & \multicolumn{2}{|c|}{$-0.96 \pm 0.18^{\mathrm{b}}$} & \multicolumn{2}{|c|}{$-0.76 \pm 0.06^{\mathrm{b}}$} \\
\hline $\mathrm{RT},{ }^{\circ} \mathrm{C}$ & $39.13 \pm 0.14$ & $39.81 \pm 0.16$ & $39.11 \pm 0.10$ & $39.46 \pm 0.16$ & $39.13 \pm 0.08$ & $39.36 \pm 0.14$ \\
\hline $\mathrm{RR} / \mathrm{min}$ & $71.63 \pm 1.64^{\mathrm{c}}$ & $93.50 \pm 1.57^{\mathrm{a}}$ & $72.63 \pm 1.85^{\mathrm{c}}$ & $84.50 \pm 1.72^{\mathrm{b}}$ & $72.88 \pm 1.72^{\mathrm{c}}$ & $81.88 \pm 1.99^{b}$ \\
\hline
\end{tabular}

Untreated= Animals not injected; T1 = Animals injected by vitamin E plus Selenium, $10 \mathrm{mg} / 10 \mathrm{~kg}$ BW; T2= Animals injected by vitamin E plus Selenium, $15 \mathrm{mg} / 10 \mathrm{~kg}$ BW; LBW =live body weight; LBWL=live body weight loss; RT= Rectal temperature; $\mathrm{RR}=$ Respiration rate.

Mean followed different superscript letter within the same row are differ $\mathrm{p}<0.05$

\section{Blood parameters:}

Hematological and biochemical parameters of the different experimental groups before transportation are presented in Tables (2 and 3). Results showed that there are no significant differences among different experimental groups in hematological and biochemical parameters before transportation.

Data of hematological and biochemical parameters of the different experimental groups after transportation are presented in Tables (4 and 5). After the 3-h. transportation, results showed that hematological parameters were improved insignificantly in the treated groups (T2 andT1) compared to untreated group. Also, results indicated that the two injected groups (T1and T2) recorded an increase in red blood cells, PCV, hemoglobin, monocyte and eosinophils concentrations in comparison with untreated group. Treated groups T1 and $\mathrm{T} 2$ had a reduction in the values of white blood cell, lymphocyte and neutrophils /lymphocyte ratio.

The present data illustrated that animals after transportation had insignificantly reduction in the values of cortisol, thyroxine, total protein, cholesterol, creatinine, urea and creatine kinase activity. While insignificantly increase in the concentrations of albumin, globulin and glucose.At the same time, the concentrations of triiodothyronine decreased and the activities of ALT and AST increased significantly $(\mathrm{P}<0.05)$ in treated groups compared to untreated group.

\section{Carcass traits:}

The present results in Table (6) showed that the injection with Viteselen 15 in treated groups led to improve insignificantly body weight, hot carcass weight, empty body, shoulder, rack, flank, tail weight and LD (longissimus dorsi) muscles area, while 
treated group at the same time led to decrease insignificantly weight of rumen content, legs, loin, neck, brisket and prime cuts. Also, results in Table
(6) illustrated that treatment to significantly $(\mathrm{P}<0.05)$ increase in dressing $\%$ and water holding capacity.

Table 2. Blood hematological parameters before transportation of sheep (mean \pm SEM)

\begin{tabular}{|c|c|c|c|}
\hline \multirow{2}{*}{ Items } & \multicolumn{3}{|c|}{ Treatments } \\
\hline & Untreated & $\mathrm{T} 1$ & $\mathrm{~T} 2$ \\
\hline No. of animals & 8 & 8 & 8 \\
\hline Red blood cells, $10^{6} / \mu 1$ & $9.25 \pm 0.70$ & $9.30 \pm 0.78$ & $9.40 \pm 0.61$ \\
\hline$(\mathrm{PCV}), \%$ & $34.88 \pm 1.01$ & $34.85 \pm 0.97$ & $34.84 \pm 0.94$ \\
\hline Hemoglobin, g/dl & $8.78 \pm 0.25$ & $8.69 \pm 0.20$ & $8.61 \pm 0.15$ \\
\hline White blood cells, $103 / \mu 1$ & $10.54 \pm 0.38$ & $10.44 \pm 0.34$ & $10.34 \pm 0.30$ \\
\hline Neutrophils, $\%$ & $39.42 \pm 0.84$ & $39.32 \pm 0.80$ & $39.42 \pm 0.81$ \\
\hline Lymphocyte, \% & $57.60 \pm 1.04$ & $57.50 \pm 1.00$ & $57.40 \pm 1.05$ \\
\hline Neutrophils / lymphocyte ratio & $0.68 \pm 0.01$ & $0.68 \pm 0.02$ & $0.69 \pm 0.05$ \\
\hline Monocyte, $\%$ & $3.33 \pm 0.15$ & $3.30 \pm 0.14$ & $3.37 \pm 0.20$ \\
\hline Eosinophil, \% & $1.87 \pm 0.07$ & $1.85 \pm 0.03$ & $1.86 \pm 0.05$ \\
\hline Basophil, \% & $0.0 \pm 0.0$ & $0.0 \pm 0.0$ & $0.0 \pm 0.0$ \\
\hline
\end{tabular}

Table 3. Some blood biochemical parameters before transportation of sheep (mean \pm SEM)

\begin{tabular}{lccc}
\hline \multirow{2}{*}{ Items } & \multicolumn{3}{c}{ Treatments } \\
\cline { 2 - 4 } & Untreated & T1 & \multicolumn{1}{c}{$\mathrm{T} 2$} \\
\hline No. of animals & 8 & 8 & $16.85 \pm 0.60$ \\
Cortisol, $\mu \mathrm{g} / \mathrm{dl}$ & $16.87 \pm 1.00$ & $16.84 \pm 0.80$ & $1.52 \pm 0.08$ \\
Triiodothyronine, $\mu \mathrm{g} / \mathrm{dl}$ & $1.54 \pm 0.04$ & $4.66 \pm 0.06$ & $4.65 \pm 0.09$ \\
Thyroxine, $\mu \mathrm{g} / \mathrm{dl}$ & $4.76 \pm 0.19$ & $6.36 \pm 0.23$ & $6.26 \pm 0.27$ \\
Total protein, g/dl & $6.46 \pm 0.16$ & $3.16 \pm 0.02$ & $3.19 \pm 0.06$ \\
Albumin, g/dl & $3.19 \pm 0.05$ & $3.20 \pm 0.28$ & $3.17 \pm 0.23$ \\
Globulin,g/dl & $3.37 \pm 0.39$ & $76.45 \pm 1.62$ & $76.45 \pm 1.63$ \\
Glucose, mg/dl & $76.55 \pm 1.71$ & $81.25 \pm 1.70$ & $81.15 \pm 1.65$ \\
Cholesterol, mg/dl & $81.35 \pm 1.78$ & $0.93 \pm 0.04$ & $0.95 \pm 0.09$ \\
Creatinine, mg/dl & $0.93 \pm 0.05$ & $16.70 \pm 0.18$ & $16.75 \pm 0.22$ \\
Urea, mg/dl & $16.71 \pm 0.26$ & $85.83 \pm 1.61$ & $85.81 \pm 1.65$ \\
Creatine kinase activity, U/l & $85.82 \pm 1.60$ & $39.26 \pm 0.80$ & $39.36 \pm 0.96$ \\
ALT, U/l & $39.16 \pm 0.90$ & $117.34 \pm 1.47$ & $117.44 \pm 1.36$ \\
AST, U/l & $117.44 \pm 1.68$ & & . \\
\hline
\end{tabular}

Untreated $=$ Animals not injected: $\mathrm{T} 1=$ Animals injected by vitamin E plus Selenium, $10 \mathrm{mg} / 10 \mathrm{~kg}$ BW; T2= Animals injected by vitamin E plus Selenium, $15 \mathrm{mg} 10 / \mathrm{kg}$ BW

Table 4 Effect of vitamin $E$ and selenium injection on hematological parameters after transportation of sheep (Mean \pm SEM).

\begin{tabular}{lccc}
\hline \multirow{2}{*}{ Items } & \multicolumn{3}{c}{ Treatments } \\
\cline { 2 - 4 } & Untreated & T1 & T2 \\
\hline No. of animals & 8 & 8 & $10.63 \pm 0.79$ \\
\hline Red blood cells $\left(10^{6} / \mu \mathrm{l}\right)$ & $9.35 \pm 0.64$ & $10.35 \pm 0.69$ & $35.68 \pm 1.11$ \\
PCV $(\%)$ & $33.23 \pm 1.21$ & $35.34 \pm 1.35$ & $9.77 \pm 0.24^{\mathrm{a}}$ \\
Hemoglobin ( g/dl) & $8.50 \pm 0.31^{\mathrm{b}}$ & $9.11 \pm 0.27^{\mathrm{ab}}$ & $10.46 \pm 0.43$ \\
White blood cells $(103 / \mu \mathrm{l})$ & $10.90 \pm 0.46$ & $10.56 \pm 0.52$ & $40.55 \pm 0.93$ \\
Neutrophils (\%) & $43.03 \pm 0.97$ & $40.85 \pm 1.02$ & $55.70 \pm 0.33$ \\
Lymphocyte (\%) & $55.81 \pm 1.12$ & $55.07 \pm 0.70$ & $0.73 \pm 0.02$ \\
Neutrophils / lymphocyte ratio & $0.77 \pm 0.01$ & $0.74 \pm 0.02$ & $3.23 \pm 0.27$ \\
Monocyte $(\%)$ & $2.75 \pm 0.19$ & $3.11 \pm 0.24$ & $1.90 \pm 0.05$ \\
Eosinophil (\%) & $1.76 \pm 0.08$ & $1.79 \pm 0.08$ & $0.0 \pm 0.0$ \\
Basophil (\%) & $0.0 \pm 0.0$ & $0.0 \pm 0.0$ & \\
\hline
\end{tabular}

Untreated $=$ Animals not injected: $\mathrm{T} 1=$ Animals injected by vitamin E plus Selenium, $10 \mathrm{mg} / 10 \mathrm{~kg} \mathrm{BW} ; \mathrm{T} 2=$ Animals injected by vitamin E plus Selenium, 15mg10/kg BW

Mean followed different superscript letter within the same row differ $\mathrm{p}<0.05$ 
Table 5. Effect of vitamin $E$ and selenium injection on some blood biochemical parameters after transportation of sheep (Mean \pm SEM)

\begin{tabular}{lccc}
\hline \multirow{2}{*}{ Items } & \multicolumn{3}{c}{ Treatments } \\
\cline { 2 - 4 } & Untreated & T1 & T2 \\
\hline No. of animals & 8 & 8 & $17.19 \pm 1.08$ \\
\hline Cortisol $(\mu \mathrm{g} / \mathrm{dl})$ & $19.83 \pm 1.18$ & $17.68 \pm 1.49$ & $1.61 \pm 0.03^{\mathrm{b}}$ \\
Triiodothyronine $(\mu \mathrm{g} / \mathrm{dl})$ & $1.87 \pm 0.12^{\mathrm{a}}$ & $1.59 \pm 0.05^{\mathrm{b}}$ & $4.09 \pm 0.25$ \\
Thyroxine $(\mu \mathrm{g} / \mathrm{dl})$ & $4.52 \pm 0.16$ & $4.24 \pm 0.20$ & $6.27 \pm 0.23$ \\
Total protein $(\mathrm{g} / \mathrm{dl})$ & $6.59 \pm 0.31$ & $6.28 \pm 0.29$ & $3.07 \pm 0.06$ \\
Albumin $(\mathrm{g} / \mathrm{dl})$ & $2.86 \pm 0.11$ & $3.05 \pm 0.16$ & $3.21 \pm 0.21$ \\
Globulin $(\mathrm{g} / \mathrm{dl})$ & $3.01 \pm 0.29$ & $3.23 \pm 0.38$ & $70.98 \pm 3.49$ \\
Glucose $(\mathrm{mg} / \mathrm{dl})$ & $63.93 \pm 3.51$ & $68.61 \pm 3.89$ & $75.97 \pm 2.26$ \\
Cholesterol $(\mathrm{mg} / \mathrm{dl})$ & $78.62 \pm 1.77$ & $76.62 \pm 2.08$ & $1.12 \pm 0.02^{\mathrm{b}}$ \\
Creatinine $(\mathrm{mg} / \mathrm{dl})$ & $1.57 \pm 0.08^{\mathrm{a}}$ & $1.23 \pm 0.06^{\mathrm{b}}$ & $17.96 \pm 0.63$ \\
Urea $(\mathrm{mg} / \mathrm{dl})$ & $19.36 \pm 0.79$ & $18.33 \pm 1.06$ & $93.39 \pm 2.41$ \\
Creatine kinase activity ( U/l) & $96.23 \pm 1.80$ & $93.74 \pm 2.00$ & $35.87 \pm 1.86^{\mathrm{a}}$ \\
ALT $(\mathrm{U} / \mathrm{l})$ & $30.59 \pm 0.70^{\mathrm{b}}$ & $33.25 \pm 1.12^{\mathrm{ab}}$ & $109.09 \pm 2.91^{\mathrm{a}}$ \\
AST $(\mathrm{U} / \mathrm{l})$ & $100.79 \pm 1.66^{\mathrm{b}}$ & $106.08 \pm 2.30^{\mathrm{ab}}$ & \\
\hline
\end{tabular}

Untreated= Animals not injected: $\mathrm{T} 1=$ Animals injected by vitamin E plus Selenium, $10 \mathrm{mg} / 10 \mathrm{~kg} \mathrm{BW}$; $\mathrm{T} 2=$ Animals injected by vitamin E plus Selenium, $15 \mathrm{mg} / 10 \mathrm{~kg}$ BW

Mean followed different superscript letter within the same row differ $\mathrm{p}<0.05$

Table 6. Effect of vitamin $E$ and selenium injection on some carcass parameters of transported Sheep (Mean \pm SEM)

\begin{tabular}{|c|c|c|c|}
\hline \multirow[t]{2}{*}{ Items } & \multicolumn{3}{|c|}{ Treatments } \\
\hline & Untreated & $\mathrm{T} 1$ & $\mathrm{~T} 2$ \\
\hline No. of animals & 3 & 3 & 3 \\
\hline Body weight (kg) & $38.13 \pm 1.27$ & $38.43 \pm 1.11$ & $39.34 \pm 0.98$ \\
\hline Hot carcass weight ( $\mathrm{kg}$ ) & $17.92 \pm 0.64$ & $18.12 \pm 0.55$ & $19.14 \pm 0.49$ \\
\hline Rumen content (kg) & $3.69 \pm 0.30$ & $3.47 \pm 0.45$ & $3.65 \pm 0.24$ \\
\hline Empty body weight ( $\mathrm{kg}$ ) & $34.45 \pm 1.31$ & $34.96 \pm 0.81$ & $35.69 \pm 0.79$ \\
\hline Shoulder $(\mathrm{kg}) 1$ & $3.36 \pm 0.10$ & $3.30 \pm 0.19$ & $3.60 \pm 0.26$ \\
\hline Legs $(\mathrm{kg}) 2$ & $5.82 \pm 0.30^{\mathrm{ab}}$ & $5.24 \pm 0.11^{\mathrm{b}}$ & $6.290 \pm 0.14^{\mathrm{a}}$ \\
\hline Loin $(\mathrm{kg}) 3$ & $1.26 \pm 0.28$ & $1.18 \pm 0.06$ & $1.15 \pm 0.10$ \\
\hline $\operatorname{Neck}(\mathrm{kg})$ & $1.18 \pm 0.13$ & $1.12 \pm 0.08$ & $1.20 \pm 0.04$ \\
\hline Rack (kg) 4 & $3.67 \pm 0.17$ & $4.12 \pm 0.23$ & $4.12 \pm 0.05$ \\
\hline Brisket (kg) & $0.76 \pm 0.04$ & $0.73 \pm 0.03$ & $0.55 \pm 0.13$ \\
\hline Flank (kg) & $0.84 \pm 0.11$ & $1.01 \pm 0.09$ & $0.91 \pm 0.04$ \\
\hline Tail $(\mathrm{kg})$ & $1.03 \pm 0.27$ & $1.43 \pm 0.37$ & $1.33 \pm 0.13$ \\
\hline Dressing (\%) & $46.98 \pm 0.10^{\mathrm{b}}$ & $47.13 \pm 0.08^{\mathrm{b}}$ & $48.65 \pm 0.03^{\mathrm{a}}$ \\
\hline Prime cuts $(\%)$ & $64.90 \pm 1.62$ & $59.80 \pm 1.63$ & $63.88 \pm 0.94$ \\
\hline L.D muscle area $\left(\mathrm{cm}^{2}\right)$ & $11.43 \pm 0.10$ & $11.50 \pm 0.15$ & $11.49 \pm 0.20$ \\
\hline $\mathrm{PH}$ value at slaughtering & $6.09 \pm 0.20^{\mathrm{a}}$ & $5.65 \pm 0.16^{\mathrm{ab}}$ & $5.35 \pm 0.15^{b}$ \\
\hline W.H.C $\left(\mathrm{cm}^{2}\right)$ & $4.42 \pm 0.07^{\mathrm{b}}$ & $5.05 \pm 0.25^{\mathrm{a}}$ & $4.91 \pm 0.15^{\mathrm{ab}}$ \\
\hline
\end{tabular}

Untreated $=$ Animals not injected: T1 = Animals injected by vitamin E plus Selenium, 10mg/10 kg BW; T2= Animals injected by vitamin E plus Selenium, $15 \mathrm{mg} / 10 \mathrm{~kg} \mathrm{BW}$

Prime cuts $=[1+2+3+4, \mathrm{~kg} /$ hot carcass weight, $\mathrm{kg}] \times 100$

$\mathrm{L} . \mathrm{D}=$ longissimus dorsi - W.H.C $=$ Water holding capacity

Mean followed by different superscript letter within the same row differ $\mathrm{p}<0.05$.

\section{DISCUSSION}

The present results showed that body weight loss and thermal parameters values were changed as a result of Viteselen 15 as antioxidant injection. According the pamphlet viteselen 15 led to immune stimulate. Generally, antioxidant injection alleviated stress of transported sheep. Antioxidants as vitamin E and selenium are free radical scavengers, which protect the body defense system against excessively produced free radicals and stabilize health status of the animal. Natural antioxidant is involved in a number of oxidation and reduction reactions in the body (Sen, 2001 and Ayo et al., 2006).

Live body weight loss after transportation in the two treated groups was less than that in untreated group. Thus, antioxidant injection before transportation alleviated live weight loss. Loss of live body weight during transportation is most probably due to loss of water (dehydration) and increasing respiration rate. High temperatures during transportation in summer might cause weight loss through loss of moisture from the respiratory tract. 
The decrease of rectal temperature and respiratory rates in injected groups with vitamin $\mathrm{E}$ and selenium as antioxidant compared to untreated group indicated that antioxidant injection ameliorated the transport stress under high environmental temperature. Antioxidant directly alters thermal set point by decreasing prostaglandin output, whose turnover increases during stress (Hadden et al., 1987) and which has a direct effect on the hypothalamic thermoregulatory zone (Ganong, 2001). The present results are in agreement with the results obtained by (Kassab and Mohammed, 2014). They reported that administration of ascorbic acid as antioxidant during transportation of sheep led to decrease thermal responses. Generally, rectal temperature and respiration rate are recognized as important measures of physiological status (Lefcourt et al., 1986) as well as ideal indicators for assessment of stress in animals.

The present results showed that after the 3-h transportation the treated groups had the highest values of red blood cells, PCV and hemoglobin. The increase in red blood cells (RBC) count in the present study may be due to changes in erythrocyte osmotic fragility upon antioxidant administration. The result of Adenkola et al. (2009 and 2010) indicated that antioxidant protect membrane integrity of erythrocyte of livestock during stress. The present results are in agreement with those of Kassab and Mohammed (2014).White blood cells(WBC) counts after transportation was slightly decreased, but still within the normal physiological range values. El khasmi et $a l,(2013)$ in camel reported that the adverse effect of transportation on the previous hematological parameters. Decreasing of neutrophil/lymphocyte ratio after 3-h. transportation in the present study as a result of antioxidant injection indicated that vitamin $\mathrm{E}$ and selenium ameliorated the stresses induced by transportation of sheep. Also, vitamin E and selenium has been reported to be a chain-breaking antioxidant, involved in the prevention and restriction of free radical chain formation and propagation, consequently, protecting blood cells, including neutrophils and lymphocytes from oxidative damage (Powers and Jackson, 2008 and Urban-Chmiel et al., 2009).

In the present study, transportation led to increased cortisol, $\mathrm{T}_{3}$, total protein, cholesterol, globulin, urea, creatinine and creatine kinase and decreased $\mathrm{T}_{4}$, AST, ALT, albumin and glucose valuesin untreated group. Three hours transportation decreased AST and ALT in sheep, but the these values of are within the normal values reported by (Duncan and Prasse, 1994). The decreases in these enzymes suggest that there is no liver damage as a results of transportation stress. The increase of urea value found following $3-\mathrm{h}$. transportation in untreated group in the present study may be due to increase protein degradation caused by hypoglycaemia. Also, the present results indicated that glucose concentrations values in untreated group decrease as a result of transportation. The present results are in agreement with those of Kassab and Mohammed
(2014). They reported that glucose concentrations in animals subjected to stressful conditions, especially during road transportation recorded lower values. In addition, our results indicated that cholesterol values were decreased after 3-h. transportation in treated groups. Percentage reduction of cholesterol values were 2.54 and $3.37 \%$ in $\mathrm{T} 1$ and $\mathrm{T} 2$ as a result of vitamin $\mathrm{E}$ and selenium injection, respectively. It has been found that antioxidant injection led to lowers serum low-density lipoprotein cholesterol and triglycerides (McRae, 2008). This means that body fat reserves are mobilized to provide energy during heat stress.

It is now a general belief that there is a negative relationship between meat quality and transport stress (Guise and Penny, 1989). The present results illustrated that antioxidant injection before transportation led to positive effect on body, hot carcass, empty body weights and dressing percent. Also, positive effect on L D muscle area, $\mathrm{pH}$ and water holding capacity of meat. At the same time transportation led to negative effect on shoulder, legs ,lion, neck, rack, brisket, flank, tail weights and prime cuts percent. The ultimate $\mathrm{pH}$ of muscle is a major determinant of meat quality (Watanabe et al., 1996) and is related to the depletion of glycogen and liberation of lactic acid pre- and post-slaughter. Transported untreated sheep group had significantly $(\mathrm{p}<0.05)$ higher ultimate $\mathrm{pH}$ values than those sheep in treated groups. Apple et al. (1995) found that muscle from stressed sheep had significantly higher ultimate $\mathrm{pH}$ values than unstressed animals and concluded that a higher $\mathrm{pH}$ than 6.0 was associated with dark meat. The effort needed by the sheep to keep their balance, while the vehicle moves is demanding in terms of energy requirements leading to depletion of glycogen and consequently decreasing muscle $\mathrm{pH}$. Glycogenolysis in skeletal muscle is regulated by the activity of glycogen phosphorylase. They also reported that the activation of this enzyme is triggered by either increasing catecholamines, muscle contraction or both. Increased metabolism of muscle glycogen during stress maybe a direct result of the calcium release into the myofibril associated with muscle contraction. On the other hand, increasing catecholamines levels can also activate glycolysis. Therefore, in the present study both of these factors may have played a role in the activation of glycolysis.

The present results illustrated that antioxidant injection led to improve water holding capacity in eye muscles as representative sample of the whole meat of sheep carcass. Water retention of meat is primarily caused by immobilization of tissue water within the myofibrillar system (Hamm, 1981). Applying pressure can cause a shift of water from the intercellular into the extracellular space and then onto the meat surface as a result of structural alterations at the level of the sarcomeres or of the myofilaments structure. The influence of transportation on expressed juice is of particular interest, where transportation did decrease level of 
expressed juice in all three muscles. The present results are in agreement with Kadim et al. (2007). They reported that negative effect of transportation at high ambient temperatures on carcass and meat quality characteristics in two age groups of sheep.

\section{CONCLUSION}

The results of the current study revealed that valuable effects of vitamin $\mathrm{E}$ and selenium (Viteselen 15) injection as antioxidant on some physiological responses such as thermal parameters and on blood hemato-biochemical parameters of sheep transported by road during the hot season. Therefore, antioxidant injection with $15 \mathrm{mg} / 10 \mathrm{~kg} \mathrm{BW}$ as anti-stress before transportation of sheep especially under hot season can be recommended.

\section{REFERENCES}

Adenkola, A.Y., J. O. Ayo, A.K.B. Sackey and A. B. Adelaiye, 2009. Haematological and serum biochemical changes in pigs administered with ascorbic acid and transported by road for four hours during the harmattan season. J. Cell Anim. Biol., 3 (2): 21-28

Adenkola, A.Y., J.O. Ayo, A. K. B. Sackey and A. B. Adelaiye, 2010. Erythrocyte osmotic fragility of pigs administered antioxidant and transported by road for short-term duration during the harmattan season. Afri. J. Biotech., 9 (2): $226-233$

Apple, J. K., M. E. Dikeman, J. E. Minton, R. M. McMurphy, M. R. Fedde, D. E. Leith and J. A. Unruh, 1995. Effects of restraint and isolation stress and epidural blockade on endocrine and blood metabolite status, muscle glycogen metabolism and incidence of dark-cutting longissimus muscle of sheep. J. Anim. Sci., 73:2295-2307.

Ayo, J. O., N. S. Minka and M. Mamman, 2006. Excitability scores of goats administered ascorbic acid and transported during hot-dry conditions. J. Vet. Sci., 7 (2): 127-131

Bernabucci, U., N. Lacetera, L. H. Baumgard, R. P. Rhoads, B. Ronchi, and A. Nardone, 2010. Metabolic and hormonal acclimation to heat stress in domesticated ruminants. Animal, 4:7:1167-1183.

Bond, J. J., L. A. Can and R. D. Warner, 2004. The effect of exercise stress, adrenaline injection and electrical stimulationon changes in quality attributes and proteins in Semimbranosus muscle of lamb. Meat Sci., 68:469-477.

Broom, D. M, 2003. Transport stress in cattle and sheep with details of physiological and other indicators. Dtsch Tierarztl Wochenschr,110: 8389.M.

Chauhan, S. S.; P Celi ;B. J Leury; I. J. Clarke and F. R. Dunshea , 2014. Dietary antioxidants at supranutritional doses improve oxidative status and reduce the negative effects of heat stress in sheep. J. Anim. Sci.,92:3364-3374.
Duncan, D.B., 1955. Multiple range and multiple F tests. Biometrics, 11:1-42.

Duncan, J. R. and K.W. Prasse, 1994.Veterinary Laboratory Medicine. ( $3^{\text {rd }}$ Ed). Iowa State University Press, Ames, USA, 10

El Khasmi, M.; Y. Chakir; F. Riad; A. Safwate; H. Tahri; M. Farh; N. El Abbadi; R. Abouhafs and B. Faye, 2013. Effects of transportation stress during the hot-dryseason on some haematological and physiological parameters in Moroccan dromedary camels (camelus dromedarius). J. Life Sci., 7: 13-25.

Farm Animal Welfare Council (FAWC), 2003. Farm Animal at Slaughter or Killing, Part 1, Defra Publication, Admail, London

Ganong, W. F., 2001. Text book of Review of Medical Physiology. Lange Medical books/Mc Graw hill Medical Publishing division. pp. 246

Guise, H. J. and R. H. C. Penny, 1989.Factors influencing thewelfare and carcass and meat quality of pigs.1. The effects ofstocking density in transport and the use of electric goads.Anim. Prod., 49:511-515.

Hadden, J. W., 1987. Neuroendocrine modulation of the thymus - dependent immune system. Annals New York Academy Sci., 496:39

Hamm, R., 1981. Post-mortem changes in muscle affecting thequality of comminuted meat products. In: (Ed. R. P. Lawrie).Development in Meat Science, Vol. 2. London, England. Applied Sci. Pub. pp. 93-124.

Henderson, W.D.;D. E. Goll; H. H. Storner and M. S. Walter, 1966.Effect of different measurement techniques and operators on bovine longissiums dorsi area. J. Agric. Sci. (camb.) 25: 334

Ingram, J. R; C.J. Cook, and P.J. Harris, 2002.The effect of transport on core and peripheral body temperatures and heart rate of sheep. Animal Welfare, 11: 103-112.

Jin, H. J., B. Y. Park, J. C. Park, I. H. Hwang, S. S. Lee, S. H. Yeon,C. D. Kim, C. Y. Cho, Y. K. Kim, K. S. Min, S. T. Feng, Z. D.Li, C. K. Park and C. I. Kim, 2006. The effects of stress related genes on carcass traits and meat quality in pigs.Asian-Aust. J.Anim. Sci., 19:280-285.

Kadim, I. T., O. Mahgoub, A.Y., AlKindi2, W., AlMarzooqi1, N. M. Al-Saqri1, M. E. Almaney, and I.Y.Mahmoud, 2007.Effect of transportation at high ambient temperatures on physiological responses, carcass and meat quality characteristics in two age groups of Omani sheep. Asian-Aust. J. Anim. Sci., 20 (3): 424 - 431

Kannan, G., B. Kouakou, T. H. Terrill and S. Gelaye, 2003.Endocrine, blood metabolite and meat quality changes in goats as influenced by shortterm, pre slaughter stress. J. Anim. Sci.,81:14991507

Kassab, A. Y. and A. A. Mohammed 2014. Ascorbic acid administration as anti-stress before transportation of sheep. Egyptian J. Anim. Prod., $51(1): 19-25$ 
Lefcourt, A.M., J. Bitman, D.L. Wood and B. Stroud, 1986.Radiotelemetry system for continuously monitoring temperature in cows. J. Dairy Sci., 69: 237-242

McRae, M. P., 2008.Vitamin C supplementation lowers serum low-density lipoprotein cholesterol and triglycerides: a meta-analysis of 13 randomized controlled trials. J. Chiropractic Med., 7: 48-58

Ministry of Agriculture, 2015. Statisticof livestock, poultry municipality and production fish statistic. Economic affairs sector, Ministry of Agriculture and land reclamation, Egypt.

Odore, R., A.D. Angelo, P. Badino, C. Bellino, S . Pagliasso, G. Re, 2004. Road transportation affects blood hormone levels and lymphocyte glucocotocoid and B-adrenergic receptors concentration in calves. Vet. J., 168: 297 - 303

Powers, S. K. and M. J. Jackson, 2008. Exerciseinduced oxidative stress: cellular mechanisms and impact on muscle force production. Physiol. Revi., 88 (4): 1243-1276

Rollin, B. E. 1995.Farm Animal Welfare.Iowa State University Press, Ames Iowa, USA.

Rooke, J. A., J. J. Robinson, and J. R. Arthur.2004. Effects of vitamin $\mathrm{E}$ and selenium on the performance and immune status of ewes and lambs. J. Agric. Sci., 142:253-262.

SAS, 2004.Statistical Analysis System.SAS statistics. Guide release, version 8.00 TS level OOMO, SAS Institute Inc., Cary, NC, USA.
Sen, C. K., 2001. Antioxidant in exercise, nutrition, sport and medicine, 31:891-908

Steinhardt, M., 2002. Reactions of young cattle from a sucklerherd to shorthaul transport by roadrepeated investigations before and after permanent separation of young cattle from their dams, Plasma cortisol, biochemical, hematological variables, minerals and heartrate, Dtsch Tierarztl Wochenschr, 109: 239-245.

Steinhardt, M. and H.H. Thielscher, 2000. Reactions of dairy calves exposed to transport stress at 60 days of age: Effects of various rearing conditions in the developmental quality of calves on physiological variables and their changes, Dtsch Tierarztl Wochensch, 107: 59-65.

Urban-Chmiel, R., M. Kankofer, A.Wernicki, E. Albera, and A. Puchalski, 2009. The influence of different doses of $\alpha$-tocopherol and ascorbic acid on selected oxidative stress parameters in in vitro culture of leucocytes isolated from transported calves. Livest. Sci., 127: 365-370

Watanabe, A., C. C. Daly and C. E. Devine, 1996. The effects of the ultimate $\mathrm{pH}$ of meat on tenderness changes during ageing. Meat Sci., 42:67-78.

Wierbicki ,E. and F.E. Deatharage, 1968. Determination of water holding capacity of fresh meat. J. Agric. Food Chem., 6(5): 387-392

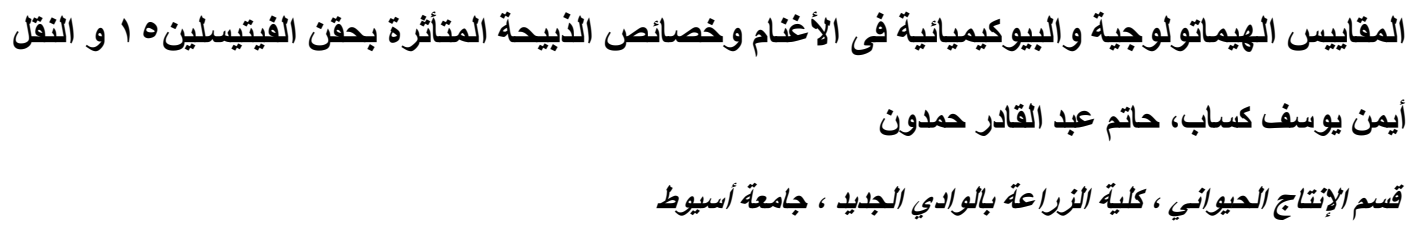

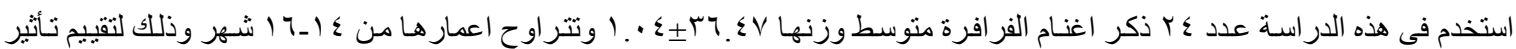

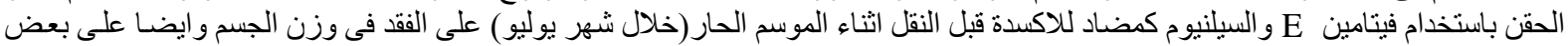

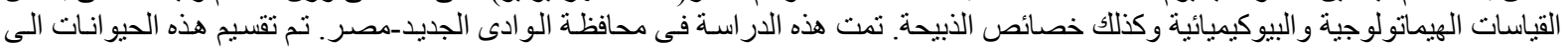

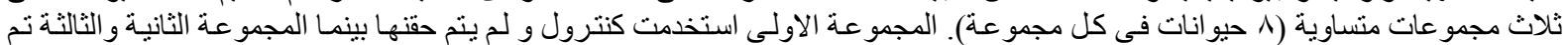

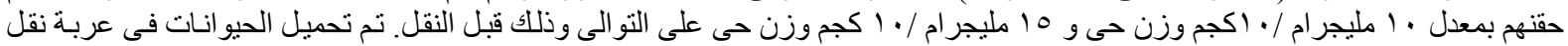

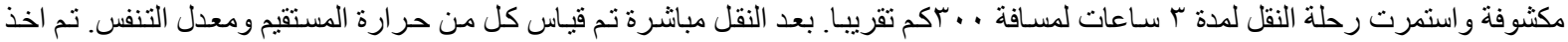

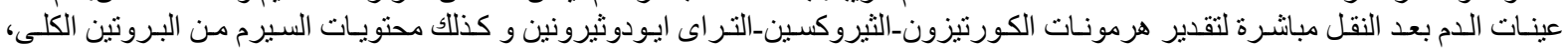

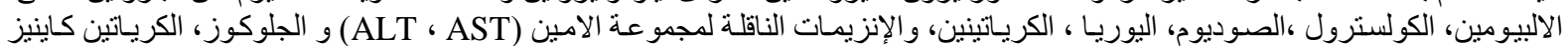

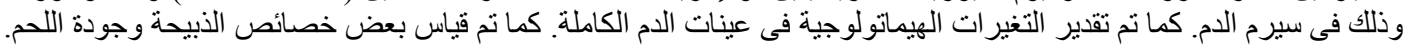

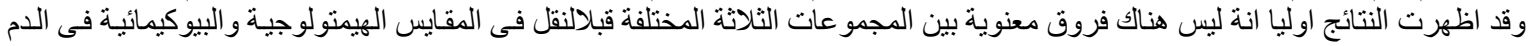

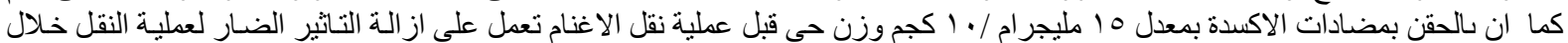

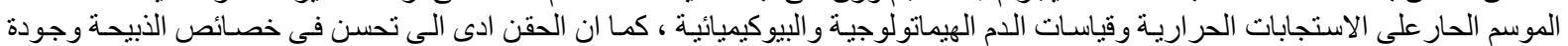

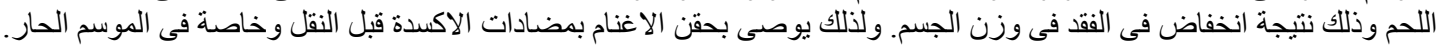

